Jurnal Sulolipu : Media Komunikasi Sivitas Akademika dan Masyarakat

Vol. 21 No. 12021

e-issn : 2622-6960, p-issn : 0854-624X

\title{
HUBUNGAN SANITASI, AIR BERSIH DAN MENCUCI TANGAN DENGAN KEJADIAN STUNTING PADA BALITA DI INDONESIA
}

Relationship of Sanitation, Clean Water, and Handwashing with Stunting in Children in Indonesia

Mitha Adzura, Fathmawati Fathmawati*, Yulia Yulia

Jurusan Kesehatan Lingkungan, Politeknik Kesehatan Kemenkes Pontianak

*email korespondensi: fathmawati@poltekkes-pontianak.ac.id

\section{ABSTRACT}

Toddler stunting is one of the most important health challenges for human growth, affecting an estimated 162 million children under five in the world. This literature study aims to determine the sanitation factors associated with stunting. This paper is sourced from articles contained in the PubMed and Google scholar database. The search for Indonesian literature was carried out with keywords: stunting, kepemilikan jamban sehat, akses air bersih, and cuci tangan dengan sabun, while for English literature searches were carried out with keywords: stunting, healthy latrines, clean water, and handwashing. The search is limited from 2014 to 2019 which can be accessed in full (full text) in pdf format and has a case-control, cross-sectional, and cohort research design. Twelve articles that met the inclusion criteria were reviewed. Ownership of healthy latrines, access to clean water, and washing hands with soap are indicated as factors causing stunting in children under five. Some of the research results that have been carried out can be considered for handling stunting through environmental interventions.

Keywords : Stunting, healthy latrines, clean water access, hand washing with soap

\section{ABSTRAK}

Stunting pada balita merupakan salah satu tantangan pada bidang kesehatan paling penting bagi pertumbuhan manusia, yang mempengaruhi sekitar 162 juta balita di dunia. Studi literatur ini bertujuan mengetahui hubungan faktor sanitasi dengan stunting. Tulisan ini bersumber dari artikel yang terdapat pada basis data PubMed dan Google scholar. Pencarian literatur bahasa Indonesia dilakukan dengan kata kunci: stunting, kepemilikan jamban sehat, akses air bersih, dan cuci tangan pakai sabun, sedangkan untuk pencarian literatur bahasa Inggris dilakukan dengan kata kunci: stunting, healthy latrines, clean water, dan hand washing. Pencarian berbatas dimulai dari tahun 2014 hingga tahun 2019 yang bisa diakses secara penuh (full text) dalam format pdf serta memiliki desain penelitian kasus kontrol, cross sectional, dan kohort. Dua belas artikel yang memenuhi kriteria inklusi kemudian ditelaah. Kepemilikan jamban sehat, akses air bersih, dan cuci tangan pakai sabun diindikasikan sebagai faktor penyebab stunting pada balita. Beberapa hasil penelitian yang telah dilakukan dapat dijadikan dipertimbangkan untuk melakukan penanganan stunting melalui intervensi lingkungan. Kata kunci : Stunting, Jamban Sehat, Akses Air Bersih, Cuci Tangan Pakai Sabun

\section{PENDAHULUAN}

Pengertian pendek dan sangat pendek menurut Keputusan Menteri Kesehatan Nomor 1995/MENKES/SK/XII/2010 tentang Standar Antropometri Penilaian Status Gizi Anak adalah status gizi yang didasarkan pada indeks Panjang Badan menurut Umur (PB/U) atau Tinggi Badan menurut Umur (TB/U). Balita pendek (stunting) dapat diketahui jika seorang balita telah diukur tinggi badan menurut umurnya dan dibandingkan dengan standar baku Multicentre Growth Reference Study (WHO-MGRS) yang diterbitkan pada 2005. Balita dikategorikan pendek jika nilai zskornya $<-2 S D$ dan dikategorikan sangat pendek jika nilai z-skornya <-3SD (Kemenkes, 2016).

Secara global, permasalahan gizi yaitu kejadian stunting (anak pendek) dialami oleh negara-negara miskin dan negara-negara berkembang. Dampak negatif dari stunting akan menghambat perkembangan balita yang akan terus berlangsung dalam kehidupan selanjutnya. Capaian prestasi akademis yang rendah sangat berhubungan dengan kejadian stunting (Arfines \& Puspitasari, 2017) dan penghasilan yang rendah pada saat dewasa (TNP2K, 2017). Balita pendek pada saat dewasa berisiko menjadi orang yang tidak produktif dan kurang sehat serta lebih mudah terkena penyakit non infeksi/tidak menular. Oleh karena itu, produktivitas suatu bangsa di masa depan akan menurun disebabkan oleh balita pendek (stunting) yang memiliki kualitas sumber daya manusia yang buruk (Unicef, 2012).

Hasil dari Pemantauan Status Gizi (PSG) prevalensi balita stunting cenderung tinggi, sebesar $11.5 \%$ balita dilaporkan sangat pendek dan $19.3 \%$ balita dilaporkan pendek. Pada Riskesdas 2018 dilaporkan bahwa terjadi penurunan angka stunting jika dibandingkan dengan Riskesdas 2013 dari 37,2\% menjadi 30,8\% (Kemenkes, 2018).

Stunting dipengaruhi oleh berbagai faktor diantaranya adalah kerawanan pangan, sanitasi yang tidak memadai, lantai rumah dari tanah dan paparan mikotoksin (Widiyanto, Atmojo, dan Darmayanti, 2018). Penelitian yang dilakukan Hidayat dan Fuada (2011) menunjukkan hubungan antara kejadian penyakit diare dan ISPA serta sanitasi lingkungan sehat dengan status gizi anak balita berdasarkan indikator BB/U, TB/U dan $\mathrm{BB} / \mathrm{TB}$. 
Jurnal Sulolipu : Media Komunikasi Sivitas Akademika dan Masyarakat

Vol. 21 No. 12021

e-issn : 2622-6960, p-issn : 0854-624X

Sanitasi yang tidak layak merupakan faktor penyebab terjadinya stunting yang berisiko terhadap terjadinya penyakit infeksi. Rohmah \& Syahrul (2017) dan Torlesse, Cronin, Sebayang, \& Nandy (2016) melaporkan fasilitas sanitasi yang buruk dan kualitas air minum yang tidak baik adalah sebuah kombinasi yang berisiko terjadinya stunting. Hal ini selaras dengan penelitian yang dilakukan Prendergast \& Humphrey (2014) di 137 negara berkembang. Penyakit infeksi pada balita dapat terjadi akibat akses terhadap sumber air bersih dan fasilitas sanitasi yang buruk sehingga energi untuk pertumbuhan digunakan untuk melawan infeksi. Proses penyerapan gizi akan terganggu sehingga akan menghambat pertumbuhan balita.

Akses air bersih untuk rumah tangga di Indonesia Sebagian besar (53,5\%) masih berada dalam kategori kurang sampai menengah $(5-<100$ Liter per orang per hari). Sumber air yang layak adalah air minum yang terlindung, yang memiliki jarak minimal 10 meter dari sumber pencemar. DKI Jakarta merupakan provinsi yang paling tinggi dalam akses sanitasi layak (91,13\%), sedangkan persentase terendah adalah Papua sebesar $(33,06 \%)$ (BPS, 2017). Hal ini merupakan masalah penting karena dapat meningkatkan risiko terjadinya penyakit infeksi yang pada akhirnya dapat menyebabkan terjadinya stunting. Wirawan (2013) menjelaskan bahwa manfaat mencuci tangan pada air bersih yang mengalir merupakan faktor pencegah tertular flu, demam dan penyakit menular lainnya sampai dengan lebih dari $50 \%$.
Penelitian tentang hubungan sarana sanitasi, akses air bersih dan mencuci tangan dengan kejadian stunting di Indonesia pernah dilakukan oleh peneliti-peneliti dengan hasil yang berbeda, namun belum ada kajian literatur di Indonesia tentang hasil penelitianpenelitian tersebut sehingga perlu dilakukan kajian literatur tentang hubungan sarana sanitasi dengan kejadian stunting pada balita di Indonesia.

Penelitian ini bertujuan untuk mengkaji hubungan sarana sanitasi dan kebiasaan mencuci tangan dengan kejadian stunting di Indonesia.

\section{METODE}

Penelitian ini merupakan kajian literatur yang bersumber dari artikel yang diterbitkan di jurnal menggunakan basis data dari PubMed dan Google scholar. Pencarian literatur bahasa Indonesia dilakukan dengan menggunakan mesin pencari Google scholar di internet dengan kata kunci: stunting, kepemilikan jamban sehat, akses air bersih, dan cuci tangan pakai sabun, sedangkan untuk pencarian literatur bahasa Inggris dilakukan dengan menggunakan mesin pencari PubMed di internet dengan kata kunci: stunting, healthy latrines, clean water, dan hand washing. Pencarian berbatas dimulai dari tahun 2014 hingga tahun 2019 yang bisa diakses secara penuh (full text) dalam format pdf serta memiliki desain penelitian kasus kontrol, cross sectional, dan kohort. Terdapat dua belas artikel yang memenuhi kriteria inklusi kemudian diulas. Alur penyaringan artikel dapat dilihat pada Gambar 1.

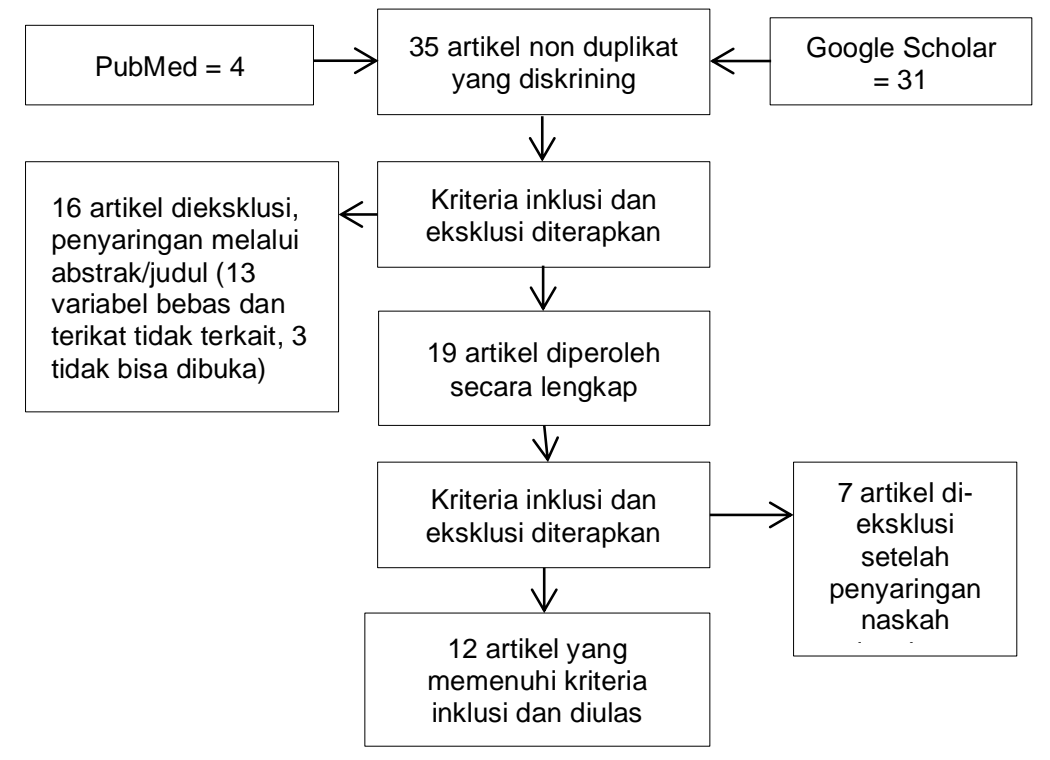

Gambar 1. Alur Penelusuran Publikasi 
Jurnal Sulolipu : Media Komunikasi Sivitas Akademika dan Masyarakat

Vol. 21 No. 12021

e-issn : 2622-6960, p-issn : 0854-624X

\section{HASIL}

Terdapat empat penelitian yang menyatakan bahwa kepemilikan jamban sehat berhubungan dengan kejadian stunting pada balita dengan kisaran nilai OR yaitu 5,25 sampai 7,93 kali. Sebaliknya, didapatkan empat penelitian yang menyatakan bahwa tidak ada hubungan antara kepemilikan jamban sehat dengan kejadian stunting pada balita dengan nilai OR yaitu 1,553 kali yang menunjukkan kepemilikan jamban sehat merupakan faktor protektif dan kepemilikan jamban yang kurang sehat merupakan faktor risiko kejadian stunting. Hasil penelusuran ini dapat dilihat pada Tabel 1.

Hasil penelusuran penelitian tentang hubungan akses air bersih dengan kejadian stunting dapat dilihat pada Tabel 2. Penulis mendapatkan sembilan penelitian yang sesuai dengan kriteria inklusi. Terdapat empat penelitian yang menyatakan bahwa akses air bersih berhubungan dengan kejadian stunting pada balita dengan kisaran nilai OR yaitu 1,21 sampai 5,99 kali. Kemudian, didapatkan lima penelitian yang menyatakan bahwa tidak ada hubungan antara akses air bersih dengan kejadian stunting pada balita dengan kisaran nilai OR yaitu 0,489 sampai 2,157 kali. Akan tetapi air bersih merupakan faktor protektif dan akses air bersih yang tidak layak dapat menjadi faktor risiko kejadian stunting.

Tabel 3 menunjukkan terdapat delapan penelitian tentang hubungan mencuci tangan pakai sabun dengan kejadian stunting yang sesuai dengan kriteria inklusi. Ada empat penelitian yang menyatakan bahwa ada hubungan yang bermakna antara mencuci tangan pakai sabun terhadap kejadian stunting dengan kisaran nilai OR yaitu 1,76 sampai 5,35 kali. Kemudian didapatkan tiga penelitian yang menyatakan bahwa tidak ada hubungan antara kebiasaan cuci tangan pakai sabun dengan kejadian stunting pada balita dengan nilai OR yaitu 0,43 sampai 1,66 kali. Namun demikian, semua penelitian menunjukkan bahwa mencuci tangan pakai sabun merupakan faktor protektif dan tidak mencuci tangan pakai sabun dapat menjadi faktor risiko kejadian stunting. 
Jurnal Sulolipu : Media Komunikasi Sivitas Akademika dan Masyarakat

Vol. 21 No. 12021

e-issn : 2622-6960, p-issn : 0854-624X

Tabel 1. Kepemilikan Jamban Sehat

\begin{tabular}{|c|c|c|c|c|c|c|c|}
\hline \multirow{2}{*}{ No } & \multirow{2}{*}{ Penulis } & \multirow{2}{*}{$\begin{array}{c}\text { Tempat } \\
\text { penelitian }\end{array}$} & \multirow{2}{*}{$\begin{array}{l}\text { Jumlah } \\
\text { Sampel }\end{array}$} & \multirow{2}{*}{ Usia } & \multicolumn{2}{|c|}{ Kelompok } & \multirow{2}{*}{ Outcome } \\
\hline & & & & & Kasus & Kontrol & \\
\hline \multicolumn{8}{|c|}{ Case Control } \\
\hline 1. & $\begin{array}{l}\text { Zul Fikar } \\
\text { Ahmad, Siti } \\
\text { Surya Indah } \\
\text { Nurdin (2019) }\end{array}$ & $\begin{array}{l}\text { Kabupaten } \\
\text { Gorontalo }\end{array}$ & $\begin{array}{l}118 \\
\text { (kasus= } \\
59 ; \text { kontrol } \\
=59 \text { ) }\end{array}$ & $\begin{array}{l}24-48 \\
\text { bulan }\end{array}$ & $\begin{array}{l}30,5 \% \\
\text { responden } \\
\text { yang memiliki } \\
\text { jamban tidak } \\
\text { memenuhi } \\
\text { syarat }\end{array}$ & $\begin{array}{l}22 \% \\
\text { responden } \\
\text { yang memiliki } \\
\text { jamban tidak } \\
\text { memenuhi } \\
\text { syarat }\end{array}$ & $\begin{array}{l}\text { OR }=1,553 \text { dan } \\
p=0,403\end{array}$ \\
\hline 2. & $\begin{array}{l}\text { Amrul Hasan, } \\
\text { Haris } \\
\text { Kadarusman } \\
(2019)\end{array}$ & $\begin{array}{l}\text { Kabupaten } \\
\text { Lampung } \\
\text { Timur }\end{array}$ & $\begin{array}{l}400 \text { (kasus } \\
=200 ; \\
\text { kontrol = } \\
200 \text { ) }\end{array}$ & $\begin{array}{l}6-59 \\
\text { bulan }\end{array}$ & $\begin{array}{l}65,5 \% \\
\text { responden } \\
\text { memiliki } \\
\text { akses } \\
\text { jamban tidak } \\
\text { memenuhi } \\
\text { syarat }\end{array}$ & $\begin{array}{l}28 \% \\
\text { responden } \\
\text { memiliki } \\
\text { akses jamban } \\
\text { tidak } \\
\text { memenuhi } \\
\text { syarat }\end{array}$ & $\begin{array}{l}\text { OR=5,25 } \\
(95 \% C l: 2,98- \\
9,23)\end{array}$ \\
\hline \multicolumn{8}{|c|}{ Cross Sectional } \\
\hline 3. & Nasrul (2019) & $\begin{array}{l}\text { Kota Palu, } \\
\text { Kabupaten } \\
\text { Poso, Sigi } \\
\text { dan } \\
\text { Kabupaten } \\
\text { Banggai di } \\
\text { Provinsi } \\
\text { Sulawesi } \\
\text { Tengah. } \\
\end{array}$ & 384 & $\begin{array}{l}0-24 \\
\text { bulan }\end{array}$ & \multicolumn{2}{|c|}{$\begin{array}{l}17,2 \% \text { responden yang tidak } \\
\text { memiliki jamban }\end{array}$} & $\begin{array}{l}\mathrm{OR}=7,398 \\
\text { dan } p=0,003\end{array}$ \\
\hline 4. & $\begin{array}{l}\text { Dewi Pertiwi, } \\
\text { Hariansyah,\& } \\
\text { Prasetya (2019) }\end{array}$ & $\begin{array}{l}\text { Kelurahan } \\
\text { Mulyaharja } \\
\text { Kecamatan } \\
\text { Bogor } \\
\text { Selatan Kota } \\
\text { Bogor }\end{array}$ & 47 & $\begin{array}{l}24-59 \\
\text { bulan }\end{array}$ & \multicolumn{2}{|c|}{$\begin{array}{l}66,7 \% \text { tidak pernah } \\
\text { menggunakan jamban sehat }\end{array}$} & $\mathrm{p}=0,389$ \\
\hline 5. & $\begin{array}{l}\text { Anggraini \& } \\
\text { Rusdy (2019) }\end{array}$ & $\begin{array}{l}\text { Wilayah kerja } \\
\text { puskesmas } \\
\text { Air Bangis } \\
\text { Kabupaten } \\
\text { Pasaman } \\
\text { Barat }\end{array}$ & 200 & $\begin{array}{l}24-59 \\
\text { bulan }\end{array}$ & \multicolumn{2}{|c|}{$\begin{array}{l}\text { 83\% responden yang tidak } \\
\text { memiliki jamban }\end{array}$} & $\mathrm{p}=0,107$ \\
\hline 6. & $\begin{array}{l}\text { Torlesse et al. } \\
\text { (2016) }\end{array}$ & Indonesia & 193 & $\begin{array}{l}0-35 \\
\text { bulan }\end{array}$ & \multicolumn{2}{|c|}{$\begin{array}{l}35,3 \% \text { responden yang tidak } \\
\text { menggunakan jamban sehat }\end{array}$} & $\begin{array}{l}\mathrm{OR}=5,32 \text { dan } \\
\mathrm{p}=0,001\end{array}$ \\
\hline 7. & $\begin{array}{l}\text { Nasrul, Hafid, } \\
\text { Thaha, \& } \\
\text { Suriah, (2015) }\end{array}$ & $\begin{array}{l}\text { Kecamatan } \\
\text { Bontoramba, } \\
\text { Kabupaten } \\
\text { Jeneponto }\end{array}$ & 350 & $\begin{array}{l}6-23 \\
\text { bulan }\end{array}$ & \multicolumn{2}{|c|}{$\begin{array}{l}45,6 \% \text { responden yang } \\
\text { memiliki WC tidak tertutup }\end{array}$} & $\mathrm{p}=0,610$ \\
\hline \multicolumn{8}{|c|}{ Kohor Retrospektif } \\
\hline 8. & $\begin{array}{l}\text { Hafid, Djabu, } \\
\text { Udin, \& Nasrul } \\
\text { (2017) }\end{array}$ & $\begin{array}{l}\text { Kabupaten } \\
\text { Banggai dan } \\
\text { Sigi }\end{array}$ & 352 & $\begin{array}{l}6-23 \\
\text { bulan }\end{array}$ & $\begin{array}{l}10,2 \% \text { respond } \\
\text { yang memiliki } \\
\text { perilaku } B A B \\
\text { sembarangan }\end{array}$ & $\begin{array}{l}2,6 \% \\
\text { responden } \\
\text { yang memil } \\
\text { perilaku BA } \\
\text { sembarang }\end{array}$ & $\mathrm{p}=0,021$ \\
\hline
\end{tabular}


Jurnal Sulolipu : Media Komunikasi Sivitas Akademika dan Masyarakat

Vol. 21 No. 12021

e-issn : 2622-6960, p-issn : 0854-624X

Tabel 2. Akses Air Bersih

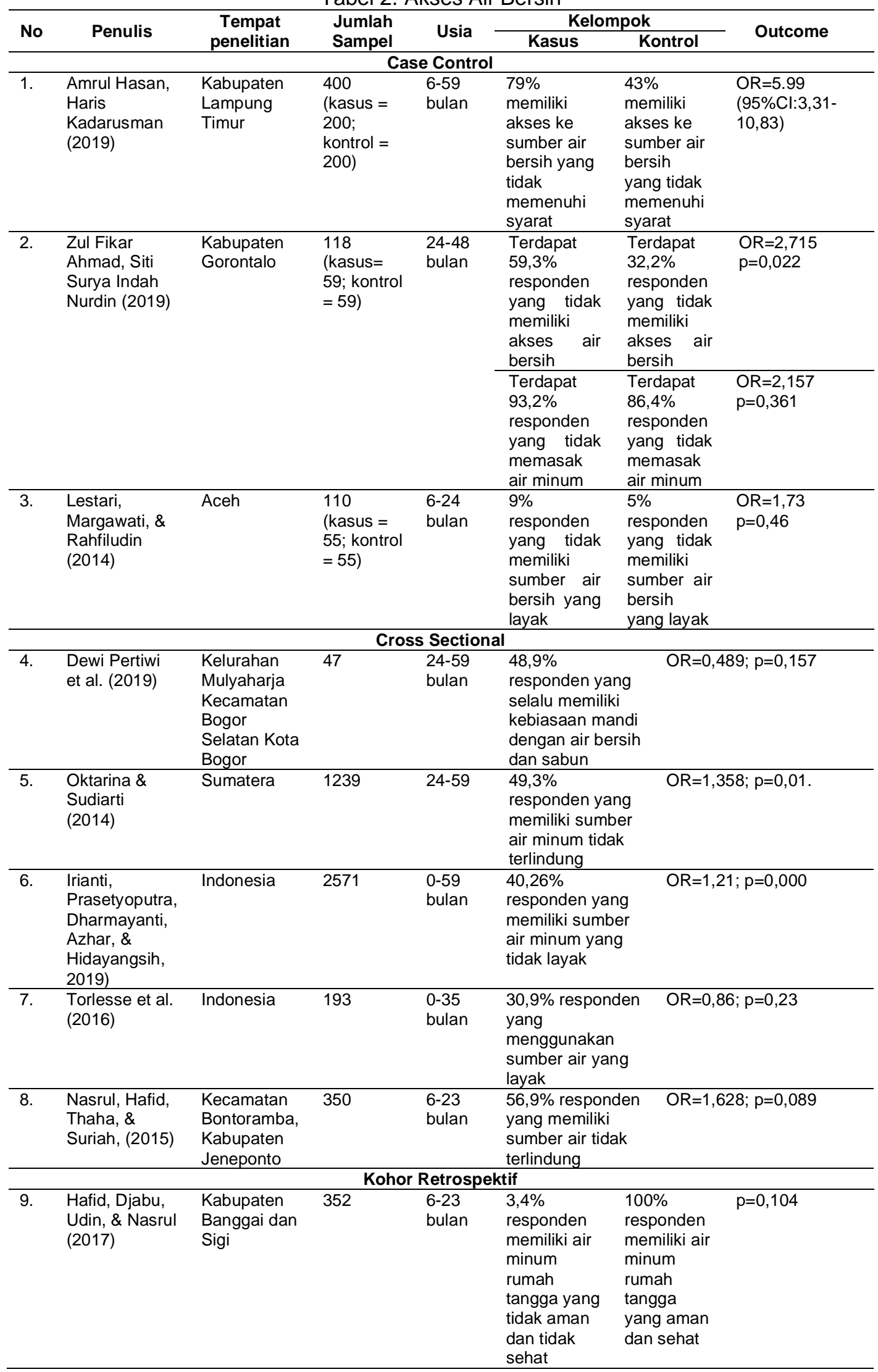


Jurnal Sulolipu : Media Komunikasi Sivitas Akademika dan Masyarakat

Vol. 21 No. 12021

e-issn : 2622-6960, p-issn : 0854-624X

Tabel 3. Cuci Tangan Pakai Sabun

\begin{tabular}{|c|c|c|c|c|c|c|c|}
\hline \multirow{2}{*}{ No } & \multirow{2}{*}{ Penulis } & \multirow{2}{*}{$\begin{array}{c}\text { Tempat } \\
\text { penelitian }\end{array}$} & \multirow{2}{*}{$\begin{array}{l}\text { Jumlah } \\
\text { Sampel }\end{array}$} & \multirow{2}{*}{ Usia } & \multicolumn{2}{|c|}{ Kelompok } & \multirow{2}{*}{ Outcome } \\
\hline & & & & & Kasus & Kontrol & \\
\hline \multicolumn{8}{|c|}{ Case Control } \\
\hline 1. & $\begin{array}{l}\text { Yuliani } \\
\text { Soeracmad, } \\
\text { Muhammad } \\
\text { lkhtiar, Agus } \\
\text { Bintara S } \\
(2019)\end{array}$ & $\begin{array}{l}\text { Puskesmas } \\
\text { Wonomulyo } \\
\text { Kabupaten } \\
\text { Polewali } \\
\text { Mandar }\end{array}$ & $\begin{array}{l}110(55 \\
\text { kasus; } 55 \\
\text { kontrol) }\end{array}$ & $\begin{array}{l}12-59 \\
\text { bulan }\end{array}$ & $\begin{array}{l}41,8 \% \\
\text { responden } \\
\text { tidak } \\
\text { mencuci } \\
\text { tangan } \\
\text { dengan } \\
\text { sabun }\end{array}$ & $\begin{array}{l}100 \% \\
\text { responden } \\
\text { yang } \\
\text { mencuci } \\
\text { tangan di } \\
\text { air } \\
\text { mengalir } \\
\text { mengguna } \\
\text { kan sabun. }\end{array}$ & $\begin{array}{l}\text { OR } 2,719,(\mathrm{Cl}) 95 \% \\
(2.064-3.581) \\
p=0,000\end{array}$ \\
\hline 2. & $\begin{array}{l}\text { Zul Fikar } \\
\text { Ahmad, Siti } \\
\text { Surya Indah } \\
\text { Nurdin } \\
\text { (2019) }\end{array}$ & $\begin{array}{l}\text { Kabupaten } \\
\text { Gorontalo }\end{array}$ & $\begin{array}{l}118(59 \\
\text { kasus; } 59 \\
\text { kontrol) }\end{array}$ & $\begin{array}{l}24-48 \\
\text { bulan }\end{array}$ & $\begin{array}{l}55,9 \% \\
\text { responden } \\
\text { yang cuci } \\
\text { tangan } \\
\text { pakai } \\
\text { sabun }\end{array}$ & $\begin{array}{l}74,6 \% \\
\text { responden } \\
\text { yang cuci } \\
\text { tangan } \\
\text { pakai } \\
\text { sabun }\end{array}$ & $\mathrm{OR}=0,433 ; p=0,053$ \\
\hline
\end{tabular}

\begin{tabular}{|c|c|c|c|c|c|c|c|}
\hline & & & Cross & ctional & & & \\
\hline 3. & $\begin{array}{l}\text { Nasrul } \\
(2019)\end{array}$ & $\begin{array}{l}\text { Kota Palu, } \\
\text { Kabupaten Poso, } \\
\text { Sigi dan } \\
\text { Kabupaten } \\
\text { Banggai di } \\
\text { Provinsi Sulawesi } \\
\text { Tengah. }\end{array}$ & 384 & $\begin{array}{l}0-24 \\
\text { bulan }\end{array}$ & \multicolumn{2}{|c|}{$\begin{array}{l}39,2 \% \text { responden } \\
\text { tidak atau kadang- } \\
\text { kadang mencuci } \\
\text { tangan }\end{array}$} & $\mathrm{OR}=5,359 ; \mathrm{p}=0,003$ \\
\hline \multirow[t]{2}{*}{4.} & \multirow[t]{2}{*}{$\begin{array}{l}\text { Dewi Pertiwi } \\
\text { et al. (2019) }\end{array}$} & \multirow[t]{2}{*}{$\begin{array}{l}\text { Kelurahan } \\
\text { Mulyaharja } \\
\text { Kecamatan Bogor } \\
\text { Selatan Kota } \\
\text { Bogor }\end{array}$} & 47 & $24-59$ & \multicolumn{2}{|c|}{$\begin{array}{l}60 \% \text { ibu kadang- } \\
\text { kadang memiliki } \\
\text { kebiasaan cuci } \\
\text { tangan sebelum } \\
\text { makan }\end{array}$} & $\mathrm{OR}=1,667 ; p=0,672$ \\
\hline & & & & & \multicolumn{2}{|c|}{$\begin{array}{l}66,7 \% \text { ibu kadang- } \\
\text { kadang melakukan } \\
\text { pembiasaan cuci } \\
\text { tangan pada anak }\end{array}$} & $\mathrm{OR}=0,489 ; p=0,157$ \\
\hline 5. & $\begin{array}{l}\text { Torlesse et } \\
\text { al. }(2016)\end{array}$ & $\begin{array}{l}\text { Indonesia (Klaten, } \\
\text { Jawa Tengah) }\end{array}$ & 193 & $\begin{array}{l}0-35 \\
\text { bulan }\end{array}$ & \multicolumn{2}{|c|}{$\begin{array}{l}25,8 \% \text { responden } \\
\text { menggunakan } \\
\text { sabun saat cuci } \\
\text { tangan }\end{array}$} & $\mathrm{OR}=1,29 ; p=0,05$ \\
\hline 6. & $\begin{array}{l}\text { Nasrul, } \\
\text { Hafid, } \\
\text { Thaha, \& } \\
\text { Suriah, } \\
\text { (2015) }\end{array}$ & $\begin{array}{l}\text { Kecamatan } \\
\text { Bontoramba, } \\
\text { Kabupaten } \\
\text { Jeneponto }\end{array}$ & 350 & $\begin{array}{l}6-23 \\
\text { bulan }\end{array}$ & \multicolumn{2}{|c|}{$\begin{array}{l}53,3 \% \text { responden } \\
\text { tidak mencuci } \\
\text { tangan }\end{array}$} & $\mathrm{OR}=1,765 ; p=0,021$ \\
\hline \multicolumn{8}{|c|}{ Kohor Retrospektif } \\
\hline 7. & $\begin{array}{l}\text { Hafid, } \\
\text { Djabu, } \\
\text { Udin, \& } \\
\text { Nasrul } \\
\text { (2017) }\end{array}$ & $\begin{array}{ll}\text { Kabupaten } & 352 \\
\text { Banggai dan } \\
\text { Sigi }\end{array}$ & $\begin{array}{l}6-23 \\
\text { bulan }\end{array}$ & $\begin{array}{l}87,7 \% \\
\text { respon } \\
\text { mencu } \\
\text { tangan } \\
\text { dengar } \\
\text { bersih } \\
\text { menga } \\
\text { pakai s }\end{array}$ & $\begin{array}{l}\text { n } \\
\text { dan } \\
\text { ir }\end{array}$ & $\begin{array}{l}99,1 \% \\
\text { responden } \\
\text { mencuci } \\
\text { tangan } \\
\text { dengan air } \\
\text { bersih } \\
\text { mengalir dan } \\
\text { pakai sabun }\end{array}$ & $p=0,000$ \\
\hline
\end{tabular}


Jurnal Sulolipu : Media Komunikasi Sivitas Akademika dan Masyarakat

Vol. 21 No. 12021

e-issn : 2622-6960, p-issn : 0854-624X

\section{PEMBAHASAN}

1. Hubungan kepemilikan jamban sehat dengan kejadian stunting

Meskipun hasil penelusuran penelitian ini menunjukkan tidak semua penelitian tentang kepemilikan jamban berhubungan dengan stunting, namun sebagian besar penelitian menunjukkan hasil bahwa keluarga yang tidak memiliki jamban berisiko memiliki anak dengan masalah stunting. Kepemilikan jamban yang tidak layak berpotensi memicu terjadinya penyakit infeksi yang dapat menganggu penyerapan nutrisi pada proses pencernaan. Bayi yang mengalami penyait infeksi dapat menurunkan berat badan bayi. Jika keadaan ini terjadi secara kronis, serta tidak diimbangi dengan pemberian makanan yang memadai dalam proses penyembuhan, akan berisiko mengakibatkan stunting (Kemenkes, 2018).

Jamban sehat mencegah terjadinya penyebaran langsung penyakit yang berasal dari kotoran manusia dan dapat mencegah vektor pembawa penyakit kontak langsung dengan tinja pengguna jamban maupun lingkungan sekitarnya (Kemenkes, 2014). Rohmah \& Syahrul (2017) yang melakukan penelitian di Sidoarjo menemukan bahwa ada hubungan antara penggunaan jamban sehat dengan kejadian diare, sementara penelitian yang dilakukan oleh Desyanti \& Nindya (2017) dan Lestari, Margawati, \& Rahfiludin (2014) menunjukkan bahwa diare pada balita berisiko terhadap kejadian stunting.

Anak-anak yang tinggal di rumah tangga yang tidak mempunyai akses jamban lebih besar risikonya menjadi stunting daripada rumah tangga yang mempunyai akses jamban (Ahmed, Barnett, \& Longhurst, 2015). Cacing parasit dapat disebarkan melalui tinja dan dapat memicu terjadinya masalah kesehatan ganda yang kompleks pada anak-anak termasuk anemia dan stunting. Peradangan usus kecil yang berulang dan terjadi dalam jangka panjang dapat menyebabkan serapan nutrisi berkurang, serta menimbulkan stunting, anemia, dan diare (Larsen, Grisham, Slawsky, \& Narine, 2017).

Beberapa penelitian menyatakan bahwa kepemilikan jamban sehat tidak mempunyai hubungan dengan kejadian stunting, namun penelitian-penelitian tersebut menunjukkan bahwa kepemilikan jamban sehat merupakan faktor protektif. Hal ini menunjukkan bahwa kepemilikan jamban sehat bukan satu-satunya faktor yang menyebabkan kejadian stunting. Beberapa peneliti menemukan bahwa pemberian ASI eksklusif membantu melindungi bayi dari berbagai penyakit infeksi dan menjaga pertumbuhan tubuh secara optimal (Wahdah, Juffrie, \& Huriyati, 2016). Sehingga disarankan kepada keluarga hendaknya memiliki jamban sehat di rumah agar tidak mencemari sumber air yang ada disekitar dan dapat mencegah datangnya lalat atau serangga yang dapat menjadi penular penyakit diare, serta pemberian ASI eksklusif memiliki peran penting pada bayi seperti meningkatkan sistem kekebalan tubuh pada bayi. Instansi pemerintah seperti puskesmas sebaiknya melakukan sosialisasi dan pemicuan terkait dengan Stop Buang Air Besar Sembarangan (SBAS) agar masyarakat memiliki perilaku BAB di jamban dan memiliki jamban yang sehat.

\section{Akses air bersih}

Sumber air minum terlindung dan tidak terlindung penting untuk diperhatikan. Sumber air minum terlindung contohnya adalah air dari unit pengolahan (PDAM), air kemasan, sementara sumber air minum tidak terlindung adalah air sungai, air sumur dan air hujan. Sumber air minum yang tidak terlindung lebih berisiko terhadap terjadinya diare. Diare yang terjadi secara kronis pada anak-anak dapat menghalangi mereka mencapai potensi pertumbuhannya (Unicef, 2012). Perbaikan kualitas air minum dapat mengurangi kejadian diare dan kasus kematian pada anak (Adewara \& Visser, 2011).

Hasil penelitian yang diperoleh sejalan dengan penelitian tentang dampak perlakuan air, sanitasi dan kebersihan terhadap pertumbuhan, morbiditas pada balita yang tinggal di negara berpenghasilan menengah ke bawah menunjukkan bahwa dengan meningkatkan akses dan kualitas air bersih, maka dapat meningkatkan z-skor tinggi badan pada balita menurut umur. Selain itu, peningkatan akses kualitas air bersih juga mengurangi risiko kejadian stunting sebesar 13\% (Gera, Shah, \& Sachdev, 2018). Hasil yang sama diperoleh di Etiopia yang menunjukkan bahwa air bersih, sanitasi dan kebersihan merupakan faktor prediktor kuat terhadap kejadian stunting (Abate \& Belachew, 2018).

Ulfah et al. (2018) menyatakan bahwa balita yang berasal dari keluarga yang mempunyai fasilitas air bersih memiliki prevalensi penyakit diare dan stunting lebih rendah daripada balita dari keluarga yang tidak 
Jurnal Sulolipu : Media Komunikasi Sivitas Akademika dan Masyarakat

Vol. 21 No. 12021

e-issn : 2622-6960, p-issn : 0854-624X

memiliki sarana air bersih dan kepemilikan jamban. Balita yang mengalami penyakit diare akan mengalami gangguan pertumbuhan, sehingga menyebabkan kejadian stunting. Terjadinya gangguan penyerapan zat gizi yang secara langsung menyebabkan tubuh kekurangan mikronutrien. Mikronutrien yang kurang dapat meningkatkan katabolisme, sehingga transportasi zat gizi esensial ke jaringan menjadi berkurang. Kurangnya distribusi zat gizi esensial ke jaringan akan menyebabkan balita kekurangan gizi yang secara langsung dapat menurunkan daya tahan tubuh balita dan menyebabkan balita rentan terhadap berbagai penyakit infeksi, serta dapat mengganggu perkembangan kognitif (Walker et al., 2012). Jika penyakit diare terjadi dalam jangka waktu yang lama dan sering, dapat menyebabkan gangguan pertumbuhan pada balita (Sujendran, Senarath, \& Joseph, 2015).

Beberapa penelitian yang menyatakan sumber air bersih yang layak tidak mempunyai hubungan dengan kejadian stunting, akan tetapi penelitian-penelitian tersebut menunjukkan bahwa sumber air bersih terlindungi merupakan faktor protektif. Hal ini menunjukkan bahwa sumber air bersih yang layak bukan merupakan satu-satunya faktor yang berhubungan dengan kejadian stunting. Beberapa peneliti menemukan bahwa pendidikan orang tua yang tinggi, orang tua bekerja, pendapatan keluarga tinggi menunjukkan kemampuan untuk mengakses sumber air bersih yang layak. Sehingga disarankan kepada lbu untuk selalu menggunakan air bersih, melakukan pengelolaan air minum dengan cara direbus/dimasak terlebih dahulu sebelum dikonsumsi oleh anak. Instansi pemerintah seperti PDAM sebaiknya melakukan penyediaan air bersih yang mencukupi sehingga dapat dialirkan ke rumah warga dan juga untuk puskesmas sebaiknya melakukan penyuluhan tentang cara mengolah air bersih.

\section{Cuci Tangan Pakai Sabun}

Perilaku mencuci tangan merupakan tindakan preventif terhadap berbagai penyakit. Membersihkan tangan dan jemari menggunakan air yang mengalir dengan sabun dalam penelitian merupakan determinan stunting. Penelitian di Ethiopia menunjukkan bahwa mencuci tangan sebelum berinteraksi dengan balita, atau pada saat balita makan tanpa mencuci tangan pakai sabun terlebih dahulu dapat dikaitkan dengan kejadian stunting. Balita menelan makanan/minuman yang mengandung bakteri patogen yang berasal dari tangan yang kotor (Kwami, Godfrey, Gavilan, Lakhanpaul, \& Parikh, 2019). Bakteri patogen yang tertelan dapat menyebabkan gangguan pada pencernaan dan akan berdampak pada tumbuh kembang balita.

Balita yang sering bermain di tanah dan tidak mencuci tangan pakai sabun pada air mengalir berisiko terinfeksi cacing. Dampak yang dapat terjadi dari infeksi cacing ini adalah anemia dan stunting. Anemia timbul karena zat gizi mikro seperti folat, zat besi, riboflavin, vitamin B12 dan vitamin A diserap oleh cacing. Hal ini dapat menurunkan nafsu makan balita. Jika infeksi ini tidak segera ditangani, balita akan mengalami kekurangan gizi dan berpengaruh pada pertumbuhan fisik dan mentalnya. Kondisi ini pada akhirnya memicu kejadian stunting.

Beberapa artikel yang diperoleh dalam penelitian ini menyatakan cuci tangan pakai sabun tidak mempunyai hubungan dengan kejadian stunting, akan tetapi penelitianpenelitian tersebut menunjukkan bahwa cuci tangan pakai sabun merupakan faktor protektif. $\mathrm{Hal}$ ini menunjukkan bahwa cuci tangan pakai sabun bukan merupakan satu-satunya faktor yang berhubungan dengan kejadian stunting. Lestari, Margawati, \& Rahfiludin (2014) menemukan bahwa balita diberi ASI eksklusif merupakan faktor protektif terhadap terjadinya stunting. Pemberian ASI eksklusif membantu melindungi bayi dari penyakit infeksi dan selalu mencuci tangan dilakukan oleh ibu dan balita, sehingga disarankan kepada lbu untuk memberikan ASI eksklusif agar bayi memiliki sistem imun yang tinggi, tidak mudah sakit dan Ibu sebaiknya rutin mencuci tangan menggunakan sabun dengan air mengalir setiap kali tangan kotor seperti setelah menceboki bayi/anak, setelah buang air besar, sebelum menyusui bayi, sebelum makan dan menyuapi anak, dan sebelum memegang makanan serta setelah makan. Instansi pemerintah seperti puskesmas sebaiknya melakukan penyuluhan tentang perilaku cuci tangan pakai sabun (CTPS) dengan menggunakan media informasi yang diletakkan di tempat yang strategis sehingga mudah diakses oleh masyarakat.

\section{KESIMPULAN}

Penggunaan jamban yang sehat, akses air bersih dan mencuci tangan dengan sabun merupakan faktor yang berhubungan 
Jurnal Sulolipu : Media Komunikasi Sivitas Akademika dan Masyarakat

Vol. 21 No. 12021

e-issn : 2622-6960, p-issn : 0854-624X

dengan kejadian stunting pada anak-anak di Indonesia.

\section{SARAN}

Pemerintah hendaknya meningkatkan promosi perilaku hidup bersih dan sehat kepada masyarakat dengan meningkatkan peran kader kesehatan di setiap desa sehingga dapat mencegah penyakit infeksi yang berakibat pada terjadinya stunting.

\section{UCAPAN TERIMA KASIH}

Penulis mengucapkan terima kasih kepada Kepala Unit Perpustakaan Terpadu Poltekkes Kemenkes Pontianak yang telah memfasilitasi dalam pencarian jurnal.

\section{DAFTAR PUSTAKA}

Abate, K. H., \& Belachew, T. (2018). Chronic Malnutrition Among Under Five Children of Ethiopia May Not Be Economic. A Systematic Review and Meta-Analysis. Ethiopian Journal of Health Science, 29(2), 265-277.

Adewara, S. O., \& Visser, M. (2011). Environment for Development Use of Anthropometric Measures to Analyze How Sources of Water and Sanitation Affect Children 's Health in Nigeria.

Ahmad, Z. F., \& Nurdin, S. S. I. (2019). Faktor Lingkungan dan Perilaku Orang Tua Pada Balita Stunting Di Kabupaten Gorontalo. Jurnal IImiah Umum Dan Kesehatan, 4(2), 87-96.

Ahmed, N., Barnett, I., \& Longhurst, R. (2015). Determinants of Child Undernutrition in Bangladesh Literature Review. MQSUN.

Anggraini, Y., \& Rusdy, P. H. N. (2019). Faktor Yang Berhubungan Dengan Stunting Pada Balita Di Wilayah Kerja Puskesmas Air Bangis Kabupaten Pasaman Barat. Dinamika Kesehatan Jurnal Kebidanan Dan Keperawatan, 10(2), 902-910.

Arfines, P. P., \& Puspitasari, F. D. (2017). Hubungan Stunting dengan Prestasi Belajar Anak Sekolah Dasar di Daerah Kumuh, Kotamadya Jakarta Pusat. Buletin Penelitian Kesehatan, 45(1), 45-52. https://doi.org/10.22435/bpk.v45i1.5798.45-52

BPS. (2017). Statistik Kesejahteraan Rakyat Tahun 2017.

Desyanti, C., \& Nindya, T. S. (2017). Hubungan Riwayat Penyakit Diare dan Praktik Higiene dengan Kejadian Stunting pada Balita Usia 24-59 Bulan di Wilayah Kerja Puskesmas Simolawang, Surabaya. Amerta Nutrition, 243-251.

https://doi.org/10.20473/amnt.v1.i3.2017.243-251

Dewi Pertiwi, F., Hariansyah, M., \& Prasetya, E. P. (2019). Faktor Risiko Stunting Pada Balita Dikelurahan Mulyaharja Tahun 2019. PROMOTOR Jurnal Mahasiswa Kesehatan Masyarakat, 2(5), 381-391.

Gera, T., Shah, D., \& Sachdev, H. S. (2018). Impact of Water, Sanitation and Hygiene Interventions on Growth, Non-diarrheal Morbidity and Mortality in Children Residing in Low- and Middle-income Countries: Indian Pediatrics, 55(5), 381-393.

Hafid, F., Djabu, U., Udin, \& Nasrul. (2017). Efek Program SBABS Terhadap Pencegahan Stunting Anak Baduta di Kabupaten Banggai dan Sigi. Indonesian Journal of Human Nutrition, 4(2), 79-87.

Hasan, A., \& Kadarusman, H. (2019). Akses ke Sarana Sanitasi Dasar sebagai Faktor Risiko 
Jurnal Sulolipu : Media Komunikasi Sivitas Akademika dan Masyarakat

Vol. 21 No. 12021

e-issn : 2622-6960, p-issn : 0854-624X

Kejadian Stunting pada Balita Usia 6-59 Bulan. Jurnal Kesehatan, 10(3), 413-421.

https://doi.org/10.26630/jk.v10i3.1451

Hidayat, T. S., \& Fuada, N. (2011). Hubungan Sanitasi Lingkungan, Morbiditas Dan Status Gizi

Balita Di Indonesia. Jurnal Penelitian Gizi Dan Makanan, 34(2), 104-113.

Irianti, S., Prasetyoputra, P., Dharmayanti, I., Azhar, K., \& Hidayangsih, P. S. (2019). The role of drinking water source, sanitation, and solid waste management in reducing childhood stunting in Indonesia. IOP Conference Series: Earth and Environmental Science, 344(1), 9. https://doi.org/10.1088/1755-1315/344/1/012009

Kemenkes. Sanitasi Total Berbasis Masyarakat (2014).

Kemenkes. (2018a). Laporan Provinsi Kalimantan Barat Riskesdas 2018. Laporan Riskesdas Nasional 2018, 493.

Kemenkes. (2018b). Situasi Balita Pendek (Stunting) di Indonesia. Kementerian Kesehatan Republik Indonesia.

Kemenkes, R. I. (2016). Info. Info Datin Situasi Balita Pendek, 29(2), 1-12.

https://doi.org/10.1145/379277.312726

Kwami, C. S., Godfrey, S., Gavilan, H., Lakhanpaul, M., \& Parikh, P. (2019). Water, Sanitation, and Hygiene: Linkages with Stunting in Rural Ethiopia. International Journal of Environmental Research and Public Health, 16(20), 21.

Larsen, D. A., Grisham, T., Slawsky, E., \& Narine, L. (2017). An individual-level meta-analysis assessing the impact of community-level sanitation access on child stunting, anemia, and diarrhea: Evidence from DHS and MICS surveys. PLoS Neglected Tropical Diseases, 11(6), 1-13. https://doi.org/10.1371/journal.pntd.0005591

Lestari, W., Margawati, A., \& Rahfiludin, M. Z. (2014). Faktor Risiko Stunting Pada Anak Umur 6-24 Bulan di Kecamatan Penanggalan Kota Subulussalam Provinsi Aceh. Jurnal Gizi Indonesia (The Indonesian Journal of Nutrition), 3(1), 37-45.

https://doi.org/10.14710/jgi.3.1.126-134

Nasrul. (2019). Pengendalian Faktor Risiko Stunting Anak Baduta Di Sulawesi Tengah. PROMOTIF: Jurnal Kesehatan Masyarakat, 8(2), 131-146. https://doi.org/10.31934/promotif.v8i2.495

Nasrul, Hafid, F., Thaha, A. R., \& Suriah. (2015). Faktor Risiko Stunting Usia 6-23 Bulan dl Kecamatan Bontoramba Kabupaten Jeneponto. Jurnal Media Kesehatan Masyarakat Indonesia, 11(3), 139-146. https://doi.org/http://dx.doi.org/10.30597/mkmi.v11i3

Oktarina, Z., \& Sudiarti, T. (2014). Faktor Risiko Stunting Pada Balita (24-59 Bulan) Di Sumatera. Jurnal Gizi Dan Pangan, 8(3), 177. https://doi.org/10.25182/jgp.2013.8.3.177180

Prendergast, A. J., \& Humphrey, J. H. (2014). The Stunting Syndrome in Developing Countries. Paediatrics and International Child Health, 34(4), 250-265.

https://doi.org/10.1179/2046905514Y.0000000158 
Jurnal Sulolipu : Media Komunikasi Sivitas Akademika dan Masyarakat

Vol. 21 No. 12021

e-issn : 2622-6960, p-issn : 0854-624X

Rohmah, N., \& Syahrul, F. (2017). Hubungan Kebiasaan Cuci Tangan dan Penggunaan Jamban Sehat dengan Kejadian Diare Balita. Jurnal Berkala Epidemologi, 5(1), 95-106. https://doi.org/10.20473/jbe.v5i1

Soeracmad, Y., Ikhtiar, M., \& S, A. B. (2019). Hubungan Sanitasi Lingkungan Rumah Tangga Dengan Kejadian Stunting Pada Anak Balita Di Puskesmas Wonomulyo Kabupaten Polewali Mandar Tahun 2019. J-KESMAS: Jurnal Kesehatan Masyarakat, 5(2), 138-150. https://doi.org/10.35329/jkesmas.v5i2.519

Sujendran, S., Senarath, U., \& Joseph, J. (2015). Prevalence of Stunting among Children Aged 6 to 36 Months, in the Eastern Province of Sri Lanka Journal of Nutritional Disorders \& Therapy. Journal of Nutritional Disorder \& Therapy, 5(1), 1-6. https://doi.org/10.4172/2161-

TNP2K. (2017). 100 Kabupaten/Kota Prioritas Untuk Intervensi Anak Kerdil (Stunting). Tim Nasional Percepatan Penanggulangan Kemiskinan. Jakarta Pusat.

Torlesse, H., Cronin, A. A., Sebayang, S. K., \& Nandy, R. (2016). Determinants of Stunting in Indonesian Children: Evidence from a cross-sectional survey indicate a prominent role for the water, sanitation and hygiene sector in stunting reduction. BMC Public Health, 16(1), 1-11. https://doi.org/10.1186/s12889-016-3339-8

Ulfah, E., Rahayuningsih, S. E., Herman, H., Susiarno, H., Gurnida, D. A., Gamayani, U., \& Sukandar, H. (2018). Asuhan Nutrisi dan Stimulasi dengan Status Pertumbuhan dan Perkembangan Balita Usia 12 - 36 Bulan. Global Medical and Health Communication, 6(38), 12-20. https://doi.org/http://dx.doi.org/10.29313/gmhc.v6i1.2323

Unicef. (2012). Gizi lbu \& Anak. Ringkasan Kajian.

Wahdah, S., Juffrie, M., \& Huriyati, E. (2016). Faktor risiko kejadian stunting pada anak umur 636 bulan di Wilayah Pedalaman Kecamatan Silat Hulu, Kapuas Hulu, Kalimantan Barat. Jurnal Gizi Dan Dietetik Indonesia (Indonesian Journal of Nutrition and Dietetics), 3(2), 119-130. https://doi.org/10.21927/ijnd.2015.3(2).119-130

Walker, C. L. F., Lamberti, L., Adair, L., Guerrant, R. L., Lescano, A. G., Martorell, R., ... Black, R. E. (2012). Does Childhood Diarrhea Influence Cognition Beyond the Diarrhea-Stunting Pathway? PLoS One, 7(10), 1-6. https://doi.org/10.1371/journal.pone.0047908

Widiyanto, A., Atmojo, J. T., \& Darmayanti, A. T. (2018). Pengaruh Faktor Kerawanan Pangan dan Lingkungan Terhadap Stunting. Jurnal Terpadu IImu Kesehatan, 8(1), 61-66.

Wirawan, I. M. C. (2013). @Blog Dokter. (I. Pradina, Ed.). Jakarta: PT. Mizan Publika. 